\title{
Bacterial inactivation mechanism of SC-CD and TEO combinations in watermelon and melon juices
}

\author{
Osman ERKMEN ${ }^{1 *}$ if
}

\begin{abstract}
Inactivation mechanism of supercritical carbon dioxide (SC-CD) combination with Thymbra spicata essential oil (TEO) treatments on bacteria in tryptone soy broth (TSB) and juices was investigated. Salmonella Typhimurium was significantly inactivated by 3.45 and 5.55 logs after SC-CD+TEO treatment of TBS for $35 \mathrm{~min}$ at 7.6 and $10.13 \mathrm{MPa}$ respectively. Klebsiella pneumoniae showed higher resistance to treatments than other two bacteria and Escherichia coli showed higher resistance to treatments than S. Typhimurium. Approximately 5.27, 4.68 and $3.82 \mathrm{logs}$ inactivation of $S$. Typhimurium, E. coli and K. pneumoniae were obtained in the treatment of watermelon juice with SC-CD+TEO at $10.13 \mathrm{MPa}$ after $35 \mathrm{~min}$, while 6.89, 4.82 and 4.55 logs inactivated, respectively, were observed in melon juice. Research indicated that the inactivation mechanism involves inducing cell damage, increasing membrane permeability, increasing cell rupture, precipitation of cytoplasmic contents, extracting cellular substances and lysing cells. Different sensitivities of Gram-negative bacteria to the treatments may be attributed to the differences in the cell structure, compositions of membrane and presence of capsule, pressure level and exposure time. $\mathrm{pH}$, total soluble solid and browning degree of juice did not significantly change after treatments and during 7 days of storage.
\end{abstract}

Keywords: supercritical carbon dioxide; Thymbra spicata; watermelon; melon; antimicrobial.

Practical Application: Inactivation mechanisms of Bacteria.

\section{Introduction}

Thermal heating methods are well-known and ancient techniques for reducing the microbial load of various foods. They have detrimental effects on the texture, color, flavor, aroma and nutrients of fruit products (Erkmen \& Bozoglu, 2016c). Enteric bacteria (Escherichia coli, Salmonella strains and others) are Gram-negative rods, have great importance in public health and can associate with ready-made foods (such as fruits and fruit juice), dairy and meat products and seafood and vegetables (Erkmen \& Bozoglu, 2016b). K. pneumoniae has been isolated from different foods, heated tomato juice (at $60{ }^{\circ} \mathrm{C}$ for $75 \mathrm{~min}$ ), high sugar-containing acidic foods, wastewater and intestinal tract. In these senses, the increased consumer demand and awareness for fresh-like and natural food products with high and/or maximum organoleptic quality and extended shelf life, non-thermal food preservation methods have been proposed. Nonthermal pressurized carbon dioxide $\left(\mathrm{CO}_{2}\right)$ has several advantages in the inactivation of microorganisms in foods, such as low cost, ease of removal from the product after use, generally recognized as safe, non-toxic, inflammable and environmentally friendly (Moussé et al., 2016; Silva et al., 2020). Supercritical $\mathrm{CO}_{2}(\mathrm{SC}-\mathrm{CD})$ above its critical point $\left(31^{\circ} \mathrm{C}\right.$ and 7.4 MPa) is characterized by a high density (close to liquids), a high diffusivity (close to gases), a low viscosity (as gases) and a very low surface tension. SC-CD were potentially used to inactivate microorganisms and enzymes in various foods such as watermelon, melon, milk, milk products, orange juice, apple juice, peach and carrot juice, apple juice and cheese, seeds, apple juice, peach and fresh-cut carrot, tomato juice and kimchi (Erkmen,
2000, 2012; Liu et al., 2012; Spilimbergo et al., 2013; Sikin et al., 2016; Marszałek et al., 2018; Pei et al., 2018; Wang et al., 2018).

Low limits of factors (such as $\mathrm{pH}$, heat treatment, pressure, storage temperature, moisture content and concentration of antimicrobials) are used in the application of hurdles in the processing of foods. When only one hurdle is applied in food processing, it needs high severity in the application. This can cause significant damages on the sensory and nutritional quality of foods. The preference of consumer for fewer/no chemicals in food has led to research on the use of natural antimicrobials in the food process for controlling unwanted microorganisms. Essential oils (EOs) extracted from aromatic plants are mixtures of multiple compounds. Turkey is one of the most important medicinal and aromatic plant trader country of the World (Tutar, 2018). Spices have pleasant flavor, color and aroma, as well as antioxidant functions and action as natural preservatives (Souza et al., 2020). The genus Thymbra spicata var. spicata L., belonging to Lamiaceae family, vernacular "Zahter" in Turkey, is an economically significant plant and grows naturally in the Eastern Mediterranian countries. The major components of T. spicata being essential oil (TEO) obtained from Turkey are carvacrol, terpinen-4-ol, caryophyllene oxide, $\gamma$-terpinene, p-cymene, myrcene and thymol (Tutar, 2018). The antimicrobial effects of zahter on different microorganisms have been studied (Tutar, 2018).

Watermelon (Citrullus lanatus) and melon (Cucumis melo) are very popular and widely consumed fruits in the world. They are high in vitamins, some amino acids, minerals, lycopene, 
antioxidants, and many other nutrients that protect the human body from free radicals (Ndiaye et al., 2018). They are mainly used in the raw state and their fleshes are directly consumed or transformed into juice. Juice obtained from fruit fleshes occasionally occur at the level of households or small businesses that do not very often meet the quality requirements for the international market (Sadji et al., 2018). They are suitable raw materials for the juice industry due to the high nutrient content and the pleasant aroma. The thermal processing of watermelon and melon juice results in off-flavor and undesirable color formation, and degradation of vitamins (Fonteles et al., 2012). Watermelon and melon caused 3602 illnesses, 322 hospitalizations, and 49 deaths in North America during 1973-2011 (Food and Agriculture Organization of the United Nations, 2011). The most common etiological agents reported from these juices were Salmonella enterica (47.1\%) followed by Norovirus (22.4\%), E. coli (5.9\%), Campylobacter jejuni (3.5\%) and Shigella sonnei (2.4\%) (Muller, 2014). Cross-contamination of E. coli with watermelon caused an outbreak in a restaurant (Walsh et al., 2014).

Antimicrobial activity mechanisms of SC-CD+TEO combination have not yet been evaluated in broth, and juice of watermelon and melon. Besides, no research had been conducted about the hurdle approach of SC-CD and TEO. Therefore, the overall objectives of this study were as follows: (i) to detect minimum inhibitory and bactericidal concentrations of TEO for S. Typhimurium, E. coli, and K. pneumoniae, and use minimum inhibitory concentrations in the pressure treatment; (ii) to study bacterial susceptibility to SC-CD in TSB; (iii) to study the hurdle effects of SC-CD+TEO on these bacteria in TSB, describing the mechanism of hurdle in the inactivation of bacteria; and (iv) to evaluate the efficacy of hurdle method (SC-CD+TEO) at most effective pressure level and TEO in watermelon and melon processes.

\section{Materials and methods}

\subsection{Preparation of bacterial cultures and materials}

\section{Essential oil extraction}

Thymbra spicata var. spicata was obtained from June to August in 2017 from Gaziantep (Turkey). T. spicata was obtained as dry form and did not expose to sunlight to avoid loss of active components. Dry zahter (together with leaves, flowers and stems) were ground by a mechanical grinder. Ground plant materials were placed into a Clevenger vessel with double distilled water in 1:2 (material: water) ratio through opening and hydrodistilled for three hours (Oreopoulou et al., 2019). The collection of TEO was done through condensing of the extract in the cooling vapor and collected into a graduated column. The extracted TEO was dehydrated with anhydrous sodium sulfate $\left(\mathrm{NaSO}_{4}\right)$ and kept in a sterile dark bottle $(10 \mathrm{~mL})$ at $4{ }^{\circ} \mathrm{C}$ until use in experiments.

\section{Preparation of watermelon and melon juice}

Watermelon (Citrullus lanatus) and melon (Cantaloupe melon) were obtained from a local market in Gaziantep (Turkey) and chosen according to the maturity criteria which were basically the heaviness, the sound of the fruit after tapping and not affected by any diseases. Each of them was cleaned separately, dried and completely hollowed. Fleshes were cut into small pieces to facilitate grinding and at the same time seeds were removed. After one min grinding in a sterile blender (Waring blender 7011, Waring Commercial, Torrington, USA), the solution was filtered through cheesecloth in order to separate juice and puree. The $\mathrm{pH}$ of watermelon and melon juice was 5.38 and 6.40 respectively. Juice was stored in a cold place $\left(\right.$ at $\left.4{ }^{\circ} \mathrm{C}\right)$ until use in the experiment. Fresh juice was prepared daily.

\section{Preparation of bacterial culture}

The following bacteria were used in this research: Salmonella enterica subsp. enterica var. Typhimurium KUEN 1357 (İstanbul University, İstanbul, Turkey), Escherichia coli KUEN 1504 (İstanbul University, İstanbul, Turkey) and Klebsiella pneumoniae ATCC 43816 (Manassas, VA, USA). Bacterial cultures were maintained on tryptone soy agar (TSA; Difco, Detroit) slants at $4{ }^{\circ} \mathrm{C}$ and subcultured monthly. Each bacterial was inoculated into tryptone soy broth (TSB; Difco, Detroit), incubated at $35^{\circ} \mathrm{C}$ for $24 \mathrm{~h}$ and used as a stock culture. A working culture was prepared by diluting $24 \mathrm{~h}$ stock culture using a sterile physiological saline solution (PSS, $0.85 \% \mathrm{NaCl}$ ) at a volume ratio of $1: 10$ with the final bacterial number $10^{7} \sim 10^{8}$ colony-forming unit $(\mathrm{cfu}) / \mathrm{mL}$.

\subsection{Treatments}

\section{$M I C$ and $M B C$}

The broth microdilution method (Seyyednejad et al., 2014) was performed to indicate antimicrobial activities (minimum inhibitory concentration, MIC and minimum bactericidal concentration, MBC) of TEO. Serial dilutions of TEO from 0.01 to $20.0 \mu \mathrm{g} / \mathrm{mL}$ were prepared in the sterile distilled water $+0.15 \%$ Twin- 80 . The diluted TEO was added into the test tubes containing $1.5 \mathrm{~mL}$ of TSB to provide the required TEO concentration in $2 \mathrm{~mL}$ of TSB. After adding TEO, TSB containing TEO was completed to $1.9 \mathrm{~mL}$ by the required amount of TSB. From each of bacterial working cultures, $100 \mu \mathrm{L}$ was inoculated into each of $1.9 \mathrm{~mL}$ TSB containing TEO. Therefore, the final volume of the TSB was $2.0 \mathrm{~mL}$. Final TEO concentrations in the TBS were ranged from 0.1 to $2.5 \mu \mathrm{g} / \mathrm{mL}$. Final bacterial numbers in tubes were $7.58 \times 10^{6} \mathrm{cfu} / \mathrm{mL}(6.89 \mathrm{logs})$ for $S$. Typhimurium, $5.62 \times 10^{6}$ $\mathrm{cfu} / \mathrm{mL}(6.74 \operatorname{logs})$ for $E$. coli and $4.68 \times 10^{6} \mathrm{cfu} / \mathrm{mL}(6.67 \operatorname{logs})$ for $K$. pneumonia. The tubes were vortexed to mix suspension and incubated at $35^{\circ} \mathrm{C}$ from 24 to $48 \mathrm{~h}$ in a water bath (ST-402; Nuve, İstanbul, Turkey). The water bath was shaken at $20 \mathrm{rpm}$. After incubation, the following antimicrobial activities on bacteria were predicted from tubes; (i) The lowest essential oil concentration in which microbial growth does not occur in the tube (without turbidity) was indicated as MIC $(\mu \mathrm{g} / \mathrm{mL})$; (ii) Subcultures were done starting from MIC tube to further three tubes without turbidity by streak plating onto TSA. The TSA plates were incubated at $37^{\circ} \mathrm{C}$ for $24 \mathrm{~h}$. The plates without growth (no colony formation) of bacterium are recorded as the respective TEO concentration completely killing bacterium and are indicated as $\mathrm{MBC}(\mu \mathrm{g} / \mathrm{mL})$. Control broths with tween 80 and TEO in $2 \mathrm{~mL}$ TSB tubes without microbial culture inoculation were used to check the microbial contamination. 


\subsection{Supercritical carbon dioxide processing}

Equipment

A cylindrical pressure vessel (maximum pressure tolerance level $=100.76 \mathrm{MPa}$ ) with an internal volume of $266 \mathrm{~mL}$ was used for $\mathrm{CO}_{2}$ pressurization. A schematic diagram of high-pressure $\mathrm{CO}_{2}$ treatment is illustrated in Figure 1. The vessel closure has a gas-impermeable connection for sensors, and gas inlet and outlet. A pressure manometer (Klauser Fisher, 28124-1; Kardeşler Ticaret, Gaziantep, Turkey) and copper-constantan thermocouple (Heraeus, 24313651; Teknim, Ankara, Turkey) were installed to monitor pressure and temperature of the gas in the pressure vessel. After each run, the system was cleaned with $70 \%(\mathrm{v} / \mathrm{v})$ ethanol followed by sterile distilled water to prevent possible contamination.

\section{Supercritical carbon dioxide treatments}

The following treatments were performed in this research.

- (i) Treatment of TBS with SC-CD. Five mL working bacterium culture was added into $35 \mathrm{~mL}$ of TSB, mixed and one $\mathrm{mL}$ sample was taken twice for initial cell count. Ten $\mathrm{mL}$ of TSB culture was added into sterile tubes $(110 \times 14 \mathrm{~mm})$. Three loosely capped tubes were placed into the pressure vessel, the vessel was tightly closed and immersed in a thermostated water bath (ST-402; Nuve, Istanbul, Turkey) at $25^{\circ} \mathrm{C}$. When the temperature of the vessel was equilibrated, $\mathrm{CO}_{2}$ with a purity of $99.99 \%$ (Kocerler, Gaziantep, Turkey) was introduced through the gas inlet valve from the gas cylinder into the vessel to reach the desired pressure (7.6 and $10.13 \mathrm{MPa}$ ). After the application of pressure for an exposure time (from 1 to $80 \mathrm{~min}$ ), the pressure was decreased to the atmospheric level by opening the valve slowly in one min. Immediately after treatment, one $\mathrm{mL}$ of sample from each of three tubes in duplicate was removed. Samples were analyzed for surviving bacterium;

- (ii) Treatment of TBS with the hurdle concept. The effect of SC-CD in combination with TEO was evaluated with simultaneously combined treatments on three bacterial cultures separately. A sufficient amount of TEO was added into $40 \mathrm{~mL}$ of TSB (containing $5 \mathrm{~mL}$ of working bacterium culture) to provide MIC, mixed and one $\mathrm{mL}$ sample was taken twice for initial cell count. Ten $\mathrm{mL}$ of TSB culture was added into sterile tubes. SC-CD treatments were applied as explained above (i);

- (iii) Treatment of watermelon and melon. The treatments were carried out for each of watermelon and melon juice with three bacterial cultures separately by the hurdle approach of SC-CD+TEO at $10.13 \mathrm{MPa}$ pressure and $25^{\circ} \mathrm{C}$. A working bacterial culture $(5 \mathrm{~mL})$ was centrifuged at $4000 \mathrm{rpm}$ (centrifuge $5810 \mathrm{R}$ Eppendorf, Hamburg, Germany) for $15 \mathrm{~min}$ and the pellets were washed with PSS and re-centrifuged twice in PSS and then added into $40 \mathrm{~mL}$ juice in a tube. Then sufficient amount of TEO was added into $40 \mathrm{~mL}$ juice to provide MIC, mixed and one $\mathrm{mL}$ sample was taken twice for initial cell count. Ten $\mathrm{mL}$ juice containing bacterial cells and TEO were added into

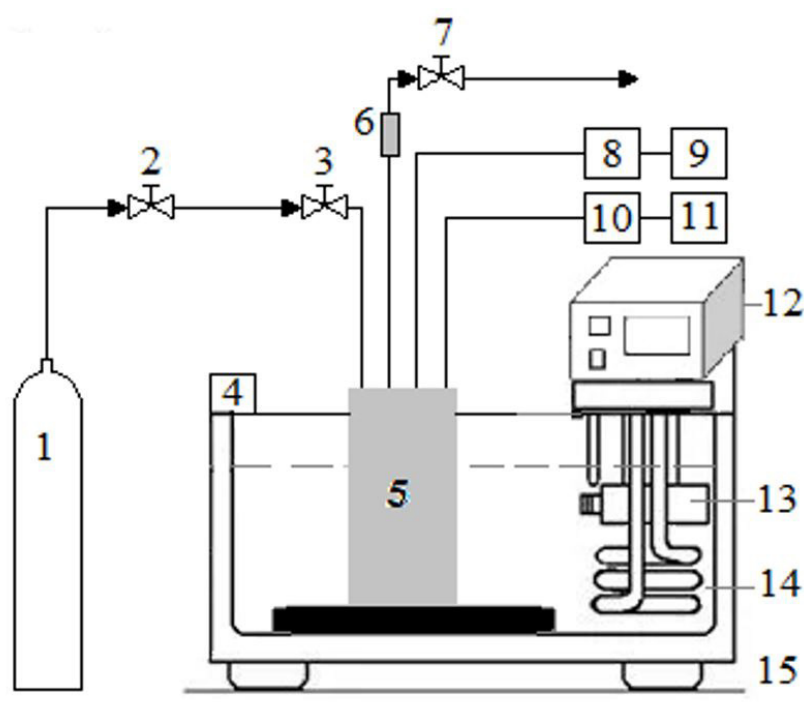

Figure 1. Schematic diagram of high-pressure $\mathrm{CO}_{2}$ treatment. (1) $=\mathrm{CO}_{2}$ cylinder; $(2)=$ pressure regulator; $(3)=$ needle valve for $\mathrm{CO}_{2}$ inlet; $(4)=$ thermostatic water bath; $(5)=$ pressure vessel; $(6)=$ line filter; $(7)=$ needle valve for $\mathrm{CO}_{2}$ outlet; $(8)=$ thermocouple; $(9)=$ temperature data logger; $(10)=$ pressure transducer; $(11)=$ pressure data logger; (12) controller; (13) water circulation pump; (14) Heater; (15) Immersion heater.

sterile tubes. SC-CD treatments were applied as explained above (i). Treated Watermelon and melon juice were stored in bottles at $4{ }^{\circ} \mathrm{C}$ until use in experiments.

\subsection{Analysis}

\section{Enumeration of bacteria}

Each sample obtained before and after treatment was diluted with PSS. The number of bacterial cells was counted by spread plating one $\mathrm{mL}$ of diluted (or non-diluted) samples on plates (in duplicate) of bismuth sulfide agar (BSA; Difco, Detroid) for $S$. Typhimurium, violet red bile agar (VRBA; Difco, Detroid) for E. coli and klebsiella chromoselect selective agar (KCSA; Merck, Interlab Laboratory Products, Adana, Turkey) supplemented with klebsiella selective supplement for $K$. pneumoniae. They were incubated at $35^{\circ} \mathrm{C}$ for $24 \mathrm{~h}$, after which all red colonies with a black zone on VRBA (Erkmen, 2015), all black colonies on BSA (Erkmen, 2015) and all purple-magenta colored colonies on KCSA (Moussé et al., 2016) were counted. Typical bacterial colonies ( 3 per plate) were streaked onto TSA slants for confirmation tests (Erkmen, 2015). The number of the bacterium was expressed as log colony-forming unit $(\mathrm{cfu} / \mathrm{mL})$. The inactivation curve was obtained by drawing $\log \left(\mathrm{cfu} / \mathrm{cfu}_{0}\right)$ versus time. Initial bacterial numbers in tubes (TSB, watermelon and melon juice) were $7.58 \times 10^{6} \mathrm{cfu} / \mathrm{mL}(6.89 \operatorname{logs})$ for $S$. Typhimurium, $5.62 \times 10^{6} \mathrm{cfu} / \mathrm{mL}(6.74 \mathrm{logs})$ for E. coli and $4.68 \times 10^{6} \mathrm{cfu} / \mathrm{mL}$ (6.67 logs) for K. pneumonia.

\subsection{Data analysis}

Biological parameters, i.e., reaction rate constant $(\mathrm{k})$ and decimal reduction in the surviving population (D), were evaluated with regression analysis of the first order rate inactivation models 
using SigmaPlot 14.0 (Systat Software, Inc., Germany). Pressure inactivation of microorganisms was assumed to follow the first order rate inactivation models expressed as Equations 1 and 2:

$$
\begin{aligned}
& \log \left(N / N_{0}\right)=-k t \\
& \log \left(N / N_{0}\right)=-t / D
\end{aligned}
$$

Where $\mathrm{N}$ = number of surviving microorganisms after a pressure treatment for time $\mathrm{t}(\mathrm{min}), \mathrm{N}_{0}=$ initial number of microorganisms and $\mathrm{k}=$ reaction rate constant $\left(\mathrm{min}^{-1}\right), \mathrm{D}=$ decimal reduction in the surviving population (min).

\subsection{Determination of changes in juice}

\section{Determination of Browning Degree (BD)}

The browning degree of watermelon and melon juice was evaluated using a spectrophotometric method described by Gui et al. (2006) Cloudy juice was centrifuged at $10000 \times \mathrm{g}$ at $4{ }^{\circ} \mathrm{C}$ for $30 \mathrm{~min}$, then passed through a $0.45 \mu \mathrm{m}$ cellulose nitrate membrane (Product no: 10401131; Global Life Sciences Technologies, Tokyo, Japan). The browning degree was determined by measuring the A (absorbance at $420 \mathrm{~nm}$ ) value using a Lamda-25 UV/VIS spectrometer (PerkinElmer, Shelton, CT, USA) at ambient temperature $\left(25 \pm 1^{\circ} \mathrm{C}\right)$ with a $1 \mathrm{~cm}$ path length cell.

\section{Determination of Total Soluble Solids (TSS)}

TSS of watermelon and melon juice was determined by the refractometer (Index Instruments, PTR 46 X, Florida, U.S). The reading from the screen was recorded as percentage soluble dry matter and expressed as in terms of ${ }^{\circ}$ Brix (Wang et al., 2018).

\section{Determination of $\mathrm{pH}$}

The $\mathrm{pH}$ values of juices were measured at $25{ }^{\circ} \mathrm{C}$ with a Corning pH meter (EM78X, Fisher, Pittsburgh, USA) equipped with a glass electrode. A $20 \mathrm{~mL}$ sample was placed in a $50 \mathrm{~mL}$ beaker with a magnetic stir bar and measurement was recorded after $\mathrm{pH}$ was stable (Erkmen, 2015).

\section{Determination of color}

CIE LAB L*, $a^{*}$ and $b^{*}$ values of juices were determined by Hunter Lab Color Flex EZ spectrophotometer (HunterLab Color Meter, Color Flex, Virginia, USA). It was standardized by white and black disks. $L^{*}, a^{*}$ and $b^{*}$ values of the disk were $93.41,-1.12$ and 1.07 respectively. The sample was well mixed before filling it into a glass cup. The glass sample cup was filled with $25 \mathrm{~mL}$ juice and placed on the sample port. The calibration white tile was placed white side down on the sample cup. Each sample was evaluated on an L (lightness), $\mathrm{a}^{*}$ (redness), $\mathrm{b}^{\star}$ (yellowness) scale at time 0 and after sitting for $10 \mathrm{~min}$. Between samples, the glass sample cup was cleaned with sterile distilled water.

\subsection{Statistical analysis}

Two samples were removed at each sampling time and experiments were repeated three times. Data were evaluated using SPSS v.22 (IBM SPSS Corporation, Chicago, IL, USA) with a 99\% confidence level. Error bars indicated in figures and \pm correspond to the standard error of the mean. A "one-way analysis of variance" (ANOVA) and "paired-samples T-test" were performed to indicate the significant effects of treatments on each bacterium.

\section{Results and discussion}

\subsection{MIC and MBC values of TEO}

The MIC values of TEO on $S$. Typhimurium, E. coli and $K$. pneumoniae were $0.35,0.45$ and $1.00 \mu \mathrm{g} / \mathrm{mL}$ respectively. The $\mathrm{MBC}$ values of TEO on these bacteria were $0.60,0.65$ and $1.5 \mu \mathrm{g} / \mathrm{mL}$ in the order. The results showed that TEO was active against all tested Gram-negative bacteria while both MIC and MBC values were higher for K. pneumoniae than the others. Capsule formation and outer membrane of Gram-negative bacteria that contains polysaccharides and lipopolysaccharides, respectively, that could act as a barrier against essential oils (EOs) (Carvalho et al., 2018). Therefore, the higher amount of TEO was required in the inactivation of capsulated Gram-negative bacteria. Thymol and carvacrol of TEO are hydrophilic compounds that can cause damages to the membranes of microbial cells (Tutar, 2018).

\subsection{Inactivation of bacteria by SC-CD and SC-CD+TEO in TSB}

Inactivation of $S$. Typhimurium after treatments at 7.6 and $10.13 \mathrm{MPa}\left(25^{\circ} \mathrm{C}\right)$ up to $80 \mathrm{~min}$ in TSB are shown in Figure 2. SC-CD+TEO was showed a higher inactivation effect on $S$. Typhimurium than SC-CD at both pressures. About 4.36 and $6.10 \operatorname{logs} S$. Typhimurium inactivation were achieved with SC$\mathrm{CD}+\mathrm{TEO}$ at 7.6 and $10.13 \mathrm{MPa}$, respectively, in $35 \mathrm{~min}$, while about 3.45 and 5.55 logs inactivation were achieved with SC-CD at the same conditions. All $S$. Typhimurium cells ( $6.89 \mathrm{logs})$ were completely inactivated after 45 and $40 \mathrm{~min}$ with SC-CD and SC-CD+TEO, respectively, at $10.13 \mathrm{MPa}$. The same inactivation occurred after 70 and 55 min with SC-CD and SC-CD+TEO, respectively, at 7.6 MPa. S. Typhimurium inactivation significantly $(\mathrm{p}<0.05)$ increased with pressure increase at both alone and combination treatments. Inactivation of $S$. Typhimurium is significantly $(p<0.05)$ higher in the combination treatments than the alone.

The inactivation of E. coli after SC-CD and SC-CD+TEO treatments at 7.6 and $10.13 \mathrm{MPa}\left(35^{\circ} \mathrm{C}\right)$ in TSB are shown in Figure 3. E. coli inactivation by SC-CD was 3.05 and 4.07 logs after $35 \mathrm{~min}$ at 7.6 and $10.13 \mathrm{MPa}$ respectively. The reduction of $E$. coli by SC-CD+TEO combination reached 3.48 and 4.91 logs after $35 \mathrm{~min}$ at 7.6 and $10.13 \mathrm{MPa}$, respectively, which were significantly $(\mathrm{p}<0.05)$ higher than $\mathrm{SC}-\mathrm{CD}$. All E. coli (6.74 logs) were inactivated in TSB after 55 and 45 min with SC-CD and SC-CD+TEO, respectively, at $10.13 \mathrm{MP}$. Inactivation of $E$. coli significantly $(p<0.05)$ increased with pressure increase at both alone and combination treatments. Inactivation of E. coli is significantly $(\mathrm{p}<0.05)$ higher in the combination treatments than alone.

Inactivation of $K$. pneumoniae after SC-CD and SC-CD+TEO treatments at 7.6 and $10.13 \mathrm{MPa}\left(25^{\circ} \mathrm{C}\right)$ in TSB are shown in 


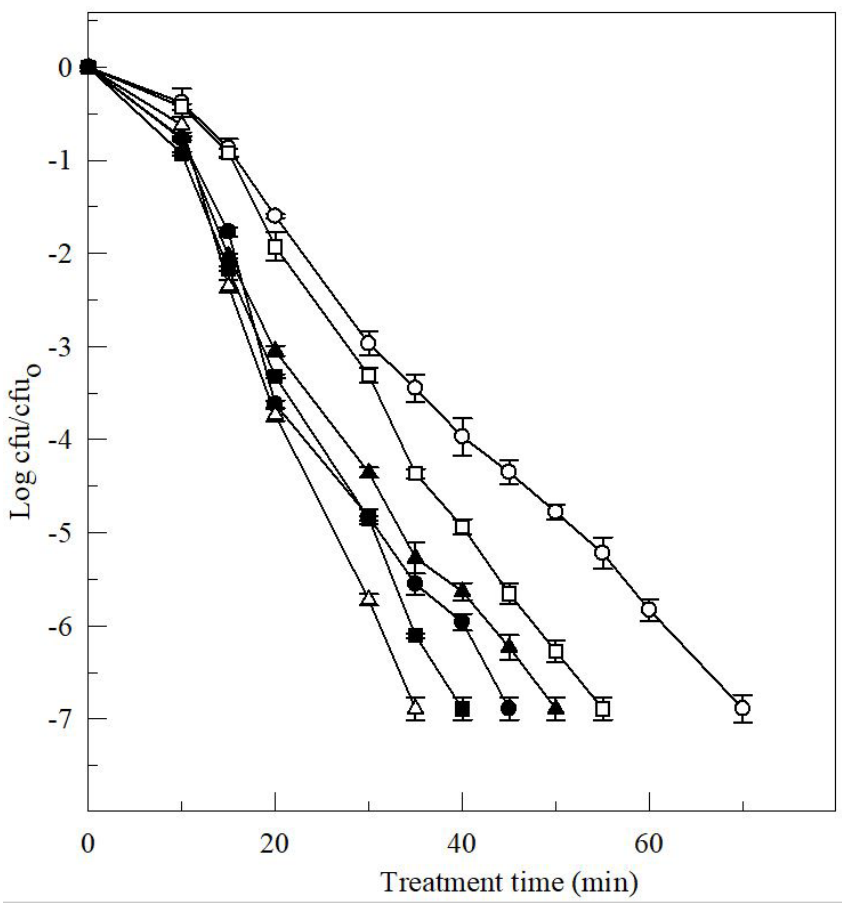

Figure 2. Antibacterial activity of SC- $\mathrm{CO}_{2}$ and $\mathrm{SC}-\mathrm{CO}_{2}+\mathrm{TEO}$ on $\mathrm{S}$. Typhimurium at $35^{\circ} \mathrm{C}$. Treatments are: $7.6 \mathrm{MPa}(\circ)$ in TSB, $10.13 \mathrm{MPa}$ $(\bullet)$ in TSB, 7.6 MPa+TEO ( $\square$ ) in TSB, 10.13 MPa+TEO (•) in TSB, 10.13 $\mathrm{MPa}+\mathrm{TEO}(\Delta)$ in watermelon and $10.13 \mathrm{MPa}+\mathrm{TEO}(\boldsymbol{\Delta})$ in melon.

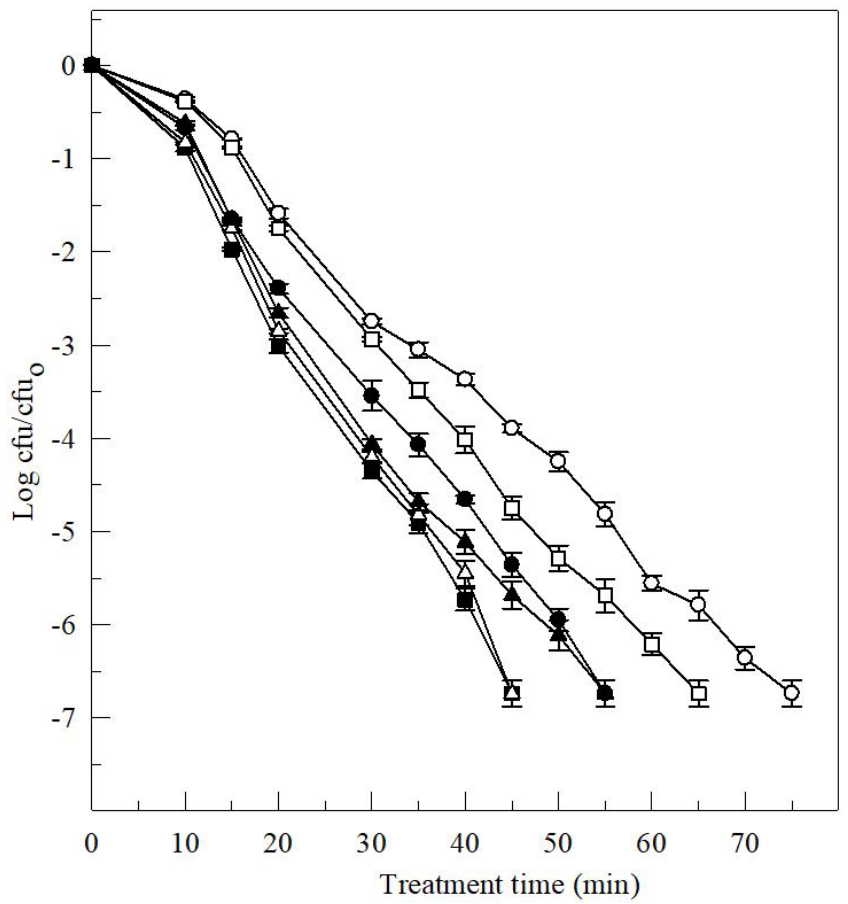

Figure 3. Antibacterial activity of $\mathrm{SC}-\mathrm{CO}_{2}$ and $\mathrm{SC}-\mathrm{CO}_{2}+\mathrm{TEO}$ on $\mathrm{E}$. coli at $25^{\circ} \mathrm{C}$. Treatments are: $7.6 \mathrm{MPa}(\circ)$ in TSB, $10.13 \mathrm{MPa}(\bullet)$ in TSB, 7.6 $\mathrm{MPa}+\mathrm{TEO}(\square)$ in TSB, $10.13 \mathrm{MPa}+\mathrm{TEO}(\bullet)$ in TSB, $10.13 \mathrm{MPa}+\mathrm{TEO}$ $(\Delta)$ in watermelon and 10.13 $\mathrm{MPa}+\mathrm{TEO}(\boldsymbol{\Delta})$ in melon.

Figure 4. After 35 min of treatment with SC-CD at 7.6 and 10.13 $\mathrm{MPa}, 2.43$ and 3.15 logs inactivation, respectively, were obtained, but a faster inactivation of $K$. pneumoniae with SC-CD+TEO

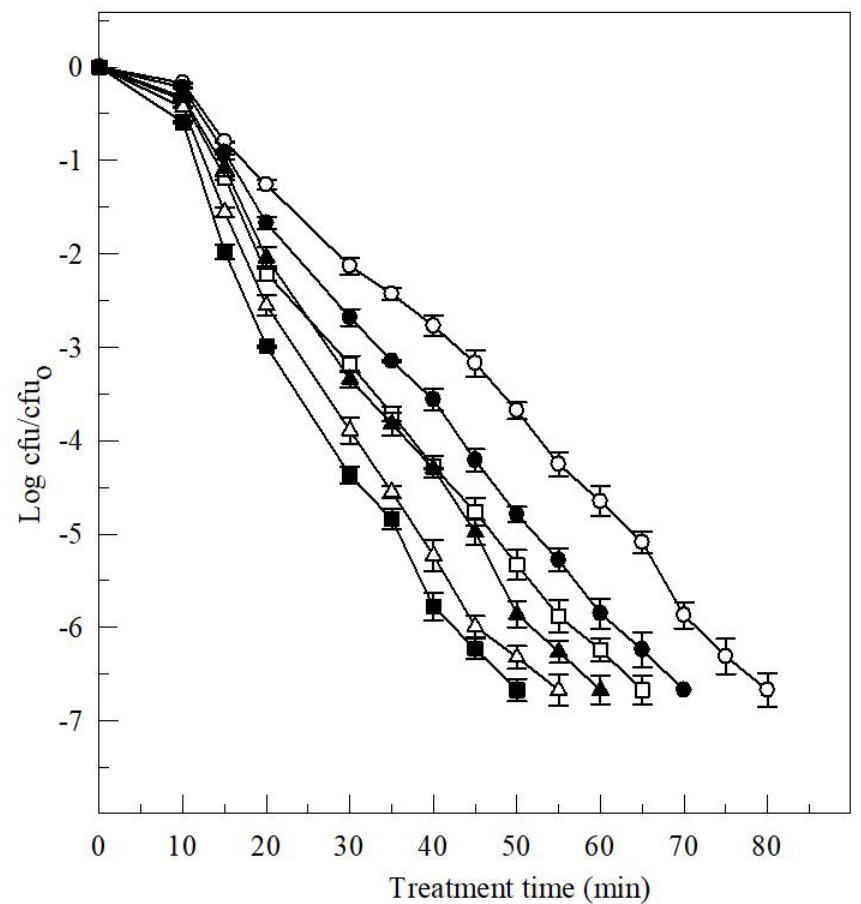

Figure 4. Antibacterial activity of $\mathrm{SC}-\mathrm{CO}_{2}$ and $\mathrm{SC}-\mathrm{CO}_{2}+\mathrm{TEO}$ on $\mathrm{K}$. pneumoniae at $35^{\circ} \mathrm{C}$. Treatments are: $7.6 \mathrm{MPa}(\mathrm{O})$ in TSB, $10.13 \mathrm{MPa}$ (•) in TSB, 7.6 MPa+TEO ( $\square$ ) in TSB, $10.13 \mathrm{MPa}+\mathrm{TEO}(\bullet)$ in TSB, 10.13 $\mathrm{MPa}+\mathrm{TEO}(\Delta)$ in watermelon and $10.13 \mathrm{MPa}+\mathrm{TEO}(\boldsymbol{\Delta})$ in melon.

was observed with 3.71 and $4.84 \operatorname{logs}$ at 7.6 and $10.13 \mathrm{MPa}$ respectively. K. pneumoniae was a capsule forming bacterium, but $S$. Typhimurium and E. coli cannot form capsule. Antimicrobial effects of SC-CD and SC-CD+EO on K. pneumoniae cells were significantly lower $(\mathrm{p}<0.05)$ than the other two bacteria. However, a large fraction of $K$. pneumoniae cells treated with SC-CD and SC-CD+TEO were significantly inactivated $(\mathrm{p}<0.05)$. The bacterial capsule is an external protective layer to the outer membrane that acts as an additional barrier primarily with long-chain repeating polysaccharides (Band \& Weiss, 2014). Moreover, SC-CD+TEO caused more antimicrobial effects $(\mathrm{p}<0.05)$ on the K. pneumoniae than SC-CD which supported the synergistic effect of combination treatments in the inactivation of capsulated bacterial cells.

$S$. Typhimurium showed higher susceptibility $(\mathrm{p}<0.05)$ to SC-CD or SC-CD+TEO than E. coli under the same conditions. Different sensitivity to the treatment between two Gram-negative pathogens may be attributed to the differences in the cell compositions especially in membranes. Four minor compounds have been detected in the structure of bacterial membranes (Ames, 1968): two partially characterized lipids, phosphatidic acid and phosphatidylserine. The phospholipid composition of the two bacteria is quite similar, the only difference is the absence of one of the minor components and a decreased level of other membrane components in E. coli. Growth conditions can also affect lipid composition (Ames, 1968). Therefore, differences in the membrane compositions may be the reasons to induce different pressure sensitivity among different bacterial strains. Due to the differences in the compositions of membranes, treatments would be shoved higher disorder effects on these 
additional components of $S$. Typhimurium. Since these effects would be increased the disorder of phospholipid structure and that would be associated with a more permeable membrane to the antimicrobial agents $\left(\mathrm{CO}_{2}\right.$ and TEO). Treatments also showed more antimicrobial effects on young cells which would be included higher numbers among $S$. Typhimurium population (with short generation time) than E. coli population (with the long generation time).

To compare the effectiveness of SC- $\mathrm{CO}_{2}$ and SC- $\mathrm{CO}_{2}+\mathrm{TEO}$ treatments on three bacteria in TSB and to optimize process conditions, the $\mathrm{k}$ and $\mathrm{D}$ values can be used to compare the inactivation rate and resistance of microorganisms. D and $\mathrm{k}$ values obtained from regression analysis are presented in Tables 1-3. For model systems, the higher the pressure in the presence of TEO the smaller the $\mathrm{D}$-value and the higher the $\mathrm{k}$ value. There were significant differences $(p<0.01)$ among $D$ and $\mathrm{k}$ values at constant pressure in TSB with and without TEO. The pressure resistance of microorganisms depends on the type of microorganism, level of pressure and presence of antimicrobial substance in the medium.

\subsection{Inactivation mechanism of bacteria with the hurdle approach}

The general mechanisms on the inactivation of microorganisms with $\mathrm{CO}_{2}$ pressure process alone were indicated (Erkmen, 2012). The precise mechanism of bacterial inactivation with the $\mathrm{SC}-\mathrm{CD}+\mathrm{EO}$ combination treatments is unclear. The possible antimicrobial mechanism of SC-CD+TEO combination on Gramnegative bacteria can be hypothesized as indicated in Figure 5. Under pressure, unhydrated $\mathrm{CO}_{2}$ can diffuse through the cellular membrane and be accumulated in the lipophilic phospholipid bilayer. This can rupture lipid-protein interactions and order loss of the lipid chain. Additionally, solubilization of $\mathrm{CO}_{2}$ in water in the environment of cells produces carbonic acid $\left(\mathrm{HCO}_{3}^{-}\right)$and $\mathrm{H}^{+}$ ion. These ions may alter the charged phospholipid groups and proteins on the surface area of the membrane, thereby altering the membrane function. At the same time, the synergistic aids can enhance the permeability of the membrane to TEO compounds and other external molecules due to the SC-CDinduced injury and damage on the cell membrane and cell wall (Figure 5a). The outer membrane and plasma membrane are the primary sites of damage for SC-CD resulting in altering the permeability and function of the membranes that can facilitate the transport of TEO through cell structures in a short time. Since, TEO compounds alone need a period time for their effect and penetration through membranes (Boskovic et al., 2017). The necessary time to inactivate cells with TEO was shortened by hurdle effects as compared with alone activity, which might cause a rapid synergistic antimicrobial effect of TEO on bacterial cells together with SC-CD. So on, TEO components easily diffused through membranes and SC-CD+TEO combination caused further disruption on the membranes with increasing permeability, acidification of cytoplasm, decreasing the $\mathrm{pH}$ gradient in the cell and altering osmoregulatory functions of the cytoplasmic membrane and cell wall. SC-CD+TEO leads to deformation on the cell structure, modifies membrane lipid, disordering the hydrocarbon lipid chains and rupturing
Table 1. Effect of SC-CO and $\mathrm{SC}-\mathrm{CO}_{2}+\mathrm{TEO}$ on the inactivation rates $(\mathrm{k})$ and decimal reduction times (D) of $S$. Typhimurium in TSB, watermelon and melon juice .

\begin{tabular}{|c|c|c|c|c|c|c|}
\hline \multirow{2}{*}{ Medium } & \multirow{2}{*}{$\begin{array}{c}\text { Pressure } \\
(\mathrm{MPa})\end{array}$} & \multicolumn{2}{|c|}{$\mathrm{k}\left(\min ^{-1}\right)$} & \multicolumn{2}{|c|}{$\mathrm{D}(\mathrm{min})$} & \multirow{2}{*}{$r^{2}$} \\
\hline & & $\bar{x}^{b}$ & $\mathrm{~s}_{\mathrm{x}}$ & $\bar{x}^{b}$ & $\mathrm{~s}_{\mathrm{x}}$ & \\
\hline \multirow{2}{*}{ TSB } & 7.6 & 0.0962 & 0.0019 & 10.40 & 0.21 & 0.98 \\
\hline & 10.1 & 0.1536 & 0.0053 & 6,5124 & 0.2259 & 0.97 \\
\hline \multirow{2}{*}{ ThymMIC-TSB } & 7.6 & 0.1211 & 0.0042 & 8,2587 & 0.2895 & 0.97 \\
\hline & 10.1 & 0.1669 & 0.0055 & 5,9907 & 0.1964 & 0.98 \\
\hline $\begin{array}{l}\text { ThymMIC+ } \\
\text { Watermelon }\end{array}$ & 10.1 & 0.1856 & 0.0115 & 5,3889 & 0.3349 & 0.95 \\
\hline ThymMIC+Melon & 10.1 & 0.1409 & 0.0030 & 7,0995 & 0.1514 & 0.99 \\
\hline
\end{tabular}

$a \bar{x}=$ means and $s_{x}=$ standard deviations of three determinations, $r^{2}=$ regression coefficient; ${ }^{\mathrm{b}}$ There are significant differences $(\mathrm{P}<0.01)$ between different treatments.

Table 2. Effect of SC-CO and $\mathrm{SC}-\mathrm{CO}_{2}+\mathrm{TEO}$ on the inactivation rates (k) and decimal reduction times (D) of E. coli in TSB, watermelon and melon juice ${ }^{\mathrm{a}}$.

\begin{tabular}{|c|c|c|c|c|c|c|}
\hline \multirow{2}{*}{ Medium } & \multirow{2}{*}{$\begin{array}{c}\text { Pressure } \\
(\mathrm{MPa})\end{array}$} & \multicolumn{2}{|c|}{$\mathrm{k}\left(\mathrm{min}^{-1}\right)$} & \multicolumn{2}{|c|}{$\mathrm{D}(\mathrm{min})$} & \multirow{2}{*}{$\mathrm{r}^{2}$} \\
\hline & & $\bar{x}^{b}$ & $\mathrm{~s}_{\mathrm{x}}$ & $\bar{x}^{b}$ & $\mathrm{~s}_{\mathrm{x}}$ & \\
\hline \multirow{2}{*}{ TSB } & 7.6 & 0.0885 & 0.0014 & 11.31 & 0.18 & 0.99 \\
\hline & 10.1 & 0.1186 & 0.0018 & 8,4282 & 0.1272 & 0.99 \\
\hline \multirow{2}{*}{ ThymMIC-TSB } & 7.6 & 0.1021 & 0.0022 & 9,7948 & 0.2087 & 0.98 \\
\hline & 10.1 & 0.1442 & 0.0031 & 6,9354 & 0.1506 & 0.99 \\
\hline $\begin{array}{l}\text { ThymMIC+ } \\
\text { Watermelon }\end{array}$ & 10.1 & 0,1401 & 0.0039 & 7,1372 & 0.1975 & 0.98 \\
\hline ThymMIC+Melon & 10.1 & 0.1255 & 0.0026 & 7,9650 & 0.1626 & 0.99 \\
\hline
\end{tabular}

Table 3. Effect of $\mathrm{SC}-\mathrm{CO}_{2}$ and $\mathrm{SC}-\mathrm{CO}_{2}+\mathrm{TEO}$ on the inactivation rates $(\mathrm{k})$ and decimal reduction times (D) of $K$. pneumonia in TSB, watermelon and melon juice ${ }^{\mathrm{a}}$.

\begin{tabular}{|c|c|c|c|c|c|c|}
\hline \multirow{2}{*}{ Medium } & \multirow{2}{*}{$\begin{array}{c}\text { Pressure } \\
(\mathrm{MPa})\end{array}$} & \multicolumn{2}{|c|}{$\mathrm{k}\left(\mathrm{min}^{-1}\right)$} & \multicolumn{2}{|c|}{$\mathrm{D}(\mathrm{min})$} & \multirow{2}{*}{$\mathrm{r}^{2}$} \\
\hline & & $\bar{x}^{b}$ & $s_{x}$ & $\bar{x}^{b}$ & $\mathrm{~s}_{\mathrm{x}}$ & \\
\hline \multirow{2}{*}{ TSB } & 7.6 & 0.0785 & 0.0018 & 12,7310 & 0.2837 & 0.98 \\
\hline & 10.1 & 0.0940 & 0.0018 & 10,6337 & 0.2056 & 0.98 \\
\hline \multirow{2}{*}{ ThymMIC-TSB } & 7.6 & 0.1046 & 0.0018 & 9,5593 & 0.1649 & 0.99 \\
\hline & 10.1 & 0.1383 & 0.0035 & 7,2324 & 0.1809 & 0.98 \\
\hline $\begin{array}{l}\text { ThymMIC+ } \\
\text { Watermelon }\end{array}$ & 10.1 & 0.1263 & 0.0031 & 7,9150 & 0.1946 & 0.98 \\
\hline ThymMIC+Melon & 10.1 & 0.1107 & 0.0027 & 9,0293 & 0.2206 & 0.98 \\
\hline
\end{tabular}

${ }^{\mathrm{a}} \overline{\mathrm{X}}=$ means and $\mathrm{s}_{\mathrm{x}}=$ standard deviations of three determinations, $\mathrm{r}^{2}=$ regression

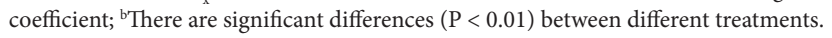

interactions of lipid-protein. This can cause order loss of the lipid chain (phase transition of phospholipid) in cell structures, the perforation of the cytoplasmic membrane and the formation 


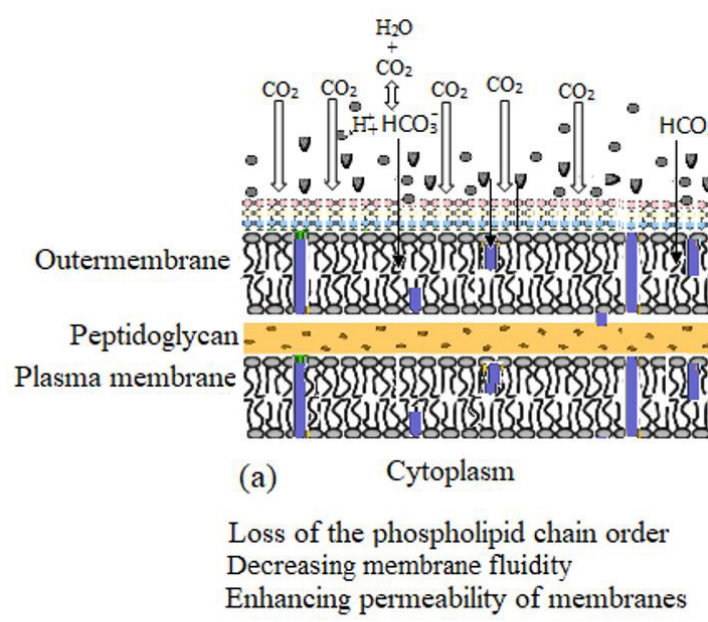

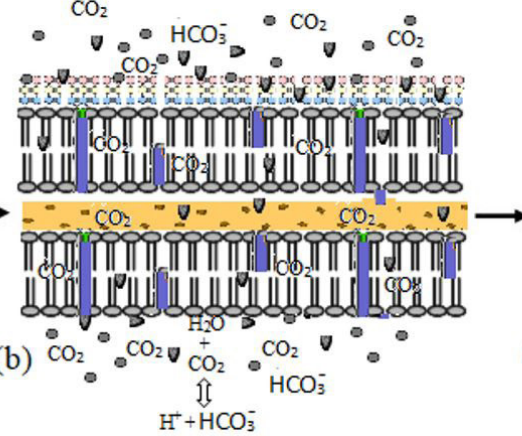

Facilitation of $\mathrm{CO}_{2}$ and TEO through cell Acidification of cytoplasm Rupturing lipid-protein interactions Pore formation

Figure 5. Mechanism of SC- $\mathrm{CO}_{2}$ and TEO actions on cell structures and cytoplasm.

of pores on membranes (Figure 5b). Chung and Yousef (Chung \& Yousef, 2008) indicated that pressure increases the lipid packing density in membranes and induces phase separations due to the differences in compressibility between lipids and proteins. Additionally, the presence of $\mathrm{HCO}_{3}{ }^{-}$and $\mathrm{H}^{+}$ions in the cytoplasm may act on the cytoplasmic charged groups, thereby coagulation of cytoplasmic contents further altering the cellular structure. Different biochemical and physical effects are involved at multiple sites on the bacterial cell surface and within the cell. Hurdle effects may include chemical modifications of the cell membrane and cytoplasm, denaturation of enzymes and proteins, and misbalancing the biological characteristics of the microbial cell. SC-CO+TEO induced the membrane phase transition and decreases membrane fluidity. Breakage of cell structures resulted in leakage of cytoplasmic components concurrently with the loss of vital cellular material (loss of ions and metabolites) and finally caused cell death (Figure 5c).

A similar bacterial inactivation mechanism was also observed on the capsulated bacteria. Combination treatments showed that pressure disorders the polysaccharide structures in the capsule and this would aid the transport of $\mathrm{CO}_{2}$ and TEO through the capsule. Due to this reason, combination treatments showed higher inactivation effects on capsulated bacteria than alone. EOs are active against E. coli, S. aureus, B. cereus and Salmonella spp. but are less effective against capsule forming bacteria that increase resistance to Eos (Martino et al., 2009).

Solubilization of $\mathrm{CO}_{2}$ in water can acidify suspension and cytoplasm by the liberation of $\mathrm{H}^{+}$ions. The effects of low external $\mathrm{pH}\left(\mathrm{pH}_{\text {ext }}\right)$ and internal $\mathrm{pH}\left(\mathrm{pH}_{\mathrm{int}}\right)$ on microbial cells are as follows: cells use too much energy that they may not able to regenerate and the low $\mathrm{pH}_{\text {ext }}$ increase permeability of membrane and peptidoglycan layer to facilitate the penetration of antimicrobials into microbial cells (Erkmen \& Bozoglu, 2016a). Low $\mathrm{pH}_{\text {int }}$ denatures several enzymes and cellular proteins, and coagulate cellular components. Enhanced concentration of $\mathrm{CO}_{2}$ and TEO in cells can easily interact with biomolecules and water, and destruct biological balance (Figure 5b). Many components of TEO that are rich in terpenes and phenolics (such as carvon, thymol and carvacrol) can penetrate into the phospholipid bilayer of the outer membrane, where they bind to proteins and prevent them from their normal functions (Juven et al., 1994).

Previous results indicated that the pressure can disrupt the peptidoglycan layer and outer membrane in the cell wall (Nazzaro et al., 2013). Some of the $S$. Typhimurium cells showed swelling after treatment with thymol and the morphology of cells remarkably altered (Nazzaro et al., 2013). The hurdle effects would occur simultaneously and synergistically under pressure. These effects cause rapid and irreversible damages on the bacterial cells, preventing synthesis of new biomolecules that would be used in the repairing damaged side of the cell wall and membranes, prevent the cell division, compromise the microbial metabolism and prevent cell growth, breaking cell structure, and all the phenomena contribute bacterial inactivation and cell death (Figure 5).

\subsection{Inactivation of bacteria in juices}

The antimicrobial activities of SC-CD+TEO combination against bacteria in watermelon and melon juice at $10.13 \mathrm{MPa}$ and $25^{\circ} \mathrm{C}$ are also given in Figures 2, 3 and 4. All S. Typhimurium (6.89), E. coli (6.74 logs) and K. pneumoniae (6.67 logs) were inactivated after 50, 55 and $60 \mathrm{~min}$, respectively, in melon juice. While higher lethality was observed in watermelon juice at the same conditions after 35,45 and 55 min respectively. About 3.73, 2.85 and $2.55 \operatorname{logs}$ of $S$. Typhimurium, E. coli and K. pneumoniae, respectively, were inactivated after $20 \mathrm{~min}$ in watermelon juice, while 3.05, 2.65 and 2.04 logs, respectively, were achieved in melon juice at the same conditions. Inactivation of bacteria in watermelon juice treated with SC-CD+TEO was significantly $(\mathrm{p}<0.05)$ higher than melon juice and TSB. This would be due to the additional synergistic effect $(\mathrm{p}<0.05)$ of the acidity of the watermelon juice ( $\mathrm{pH} 5.38)$. The results indicated the synergistic combination effect of hurdle factors (SC-CD, TEO and acidity). The effect of the pressure process decreased in melon juice due to the presence of a higher amount 
of organic components (such as carbohydrates) which immobilize and inactivate components in EOs and prevented easy diffusion of $\mathrm{CO}_{2}$ in juice (Smid \& Gorris, 2007).

The synergistic effect of EO and SC-CD observed in both TSB and juice was at least 5 min orders of magnitude decreased the inactivation time when compared to those observed with SC-CD alone. The number of cells was rapidly reduced with SC-CD and TEO combination compared with treated alone, indicating that bacteria injured by SC-CD processing might not be repaired in the presence of other hurdle factors. Previous studies suggested that the application of $\mathrm{CO}_{2}$ pressure alone caused injury to the cells (Corradini \& Peleg, 2012; Erkmen, 2012).

To compare the effectiveness of SC- $\mathrm{CO}_{2}$ and SC- $\mathrm{CO}_{2}+\mathrm{TEO}$ treatments on three bacteria in watermelon and melon juice and to optimize process conditions, the $\mathrm{k}$ and $\mathrm{D}$ values can be used to compare the inactivation rate and resistance of microorganisms. $\mathrm{D}$ and $\mathrm{k}$ values obtained from regression analysis are presented in Tables 1-3. For model systems, the higher the SC-CD pressure in the presence of TEO the smaller the D-value and the higher the $\mathrm{k}$ value. There were significant differences $(\mathrm{p}<0.01)$ among $\mathrm{D}$ and $\mathrm{k}$ values at constant pressure in watermelon and melon juice. The pressure resistance of microorganisms depends on the type of microorganism, level of pressure, and presence of antimicrobial substance and composition of the medium.

\subsection{Effect of treatments on $\mathrm{pH}$, total soluble solid, browning degree and color of juices}

The influences of the combination of SC-CD+TEO treatment on total soluble solids (TSS) and pH of juices are given in Table 4. The initial TSS values of watermelon and melon juice were 11.29 and $9.47^{\circ}$ Brix, respectively. After SC-CD+TEO treatments, TSS showed fluctuations but did not change significantly $(\mathrm{p}>0.05)$ after treatments and during storage compared with control. Hence, HPCD treatment did not affect carbohydrates (e.g. glucose, fructose and sucrose) which were the main components of TSS of watermelon juice (Liu et al., 2012). Similarly, HPCD treatment did not change TSS of carrot juice (Zhou et al., 2009) and a watermelon (Liu et al., 2012). Ultrafiltration of watermelon juice allowed an acceptable level of clarification in terms of sugar and ascorbic acid and also greatly reduced the suspended solids and the turbidity of the fresh juice (Bhattacharjee et al., 2018).

Table 4 shows the $\mathrm{pH}$ values for each juice after treatments during the 7 days storage. The initial $\mathrm{pH}$ values of watermelon and melon juices were 5.38 and 6.80. The $\mathrm{pH}$ values of the watermelon and melon juices were slightly decreased after treatments and during storage. Therefore, treatments had a significant $(\mathrm{p}<0.05)$ effect on the $\mathrm{pH}$ of juice compared with the control. There are two main reasons for the slight decrease in the $\mathrm{pH}$ value. First, the pressure may affect the ionization equilibrium of the aqueous solution. As the pressure rises, the ionization reaction of the carbonic acid in water will proceed in the direction of hydrogen ion generation, resulting in the reduction of the $\mathrm{pH}$.

The influences of the SC-CD+TEO treatment on browning degree (BD) of watermelon and melon juices are given in Table 5. The initial $\mathrm{BD}$ of treated watermelon and melon juices were 1.12 and 1.09. BD values of the treated juices were not changed significantly $(\mathrm{p}>0.05)$ after treatment and during storage.

Tables 6 and 7 show the $L^{\star}, a^{\star}$ and $b^{\star}$ values watermelon and melon juices, respectively, after treatments and during the storage. Values of $b^{*}$ were unchanged after treatments $(p>0.05)$ while $a^{*}$ value significantly $(\mathrm{p}<0.05)$ increased compared to control juices. Values of $L^{*}$ were slightly increased ( $\left.p>0.05\right)$ after treatment and during the storage of juices. Through the comparison of total color difference values, SC-CD+TEO had little effect on the color

Table 4. Effect of SC-CO+EO treatment on total soluble solids and $\mathrm{pH}$ of watermelon and melon juices.

\begin{tabular}{|c|c|c|c|c|c|c|c|c|}
\hline \multirow{3}{*}{ Day } & \multicolumn{4}{|c|}{ Watermelone juice } & \multicolumn{4}{|c|}{ Melon juice } \\
\hline & \multicolumn{2}{|c|}{ Total soluble solid } & \multicolumn{2}{|c|}{$\mathrm{pH}$} & \multicolumn{2}{|c|}{ Total soluble solid } & \multicolumn{2}{|c|}{$\mathrm{pH}$} \\
\hline & Untreated & $\mathrm{SC}-\mathrm{CO}_{2}+\mathrm{TEO}$ & Untreated & $\mathrm{SC}-\mathrm{CO}_{2}+\mathrm{TEO}$ & Untreated & $\mathrm{SC}-\mathrm{CO}_{2}+\mathrm{TEO}$ & Untreated & $\mathrm{SC}-\mathrm{CO}_{2}+\mathrm{TEO}$ \\
\hline 0 & $11.29 \pm 0.02^{\star}$ & $11.32 \pm 0.01$ & $5.38 \pm 0.01$ & $5.32 \pm 0.01$ & $9.47 \pm 0.21$ & $9.47 \pm 0.21$ & $6.80 \pm 0.15$ & $6.69 \pm 0.15$ \\
\hline 1 & $11.33 \pm 0.03$ & $11.36 \pm 0.03$ & $5.37 \pm 0.02$ & $5.30 \pm 0.02$ & $9.54 \pm 0.18$ & $9.58 \pm 0.18$ & $6.64 \pm 0.20$ & $6.62 \pm 0.14$ \\
\hline 3 & $11.28 \pm 0.03$ & $11.30 \pm 0.01$ & $5.35 \pm 0.01$ & $5.28 \pm 0.01$ & $9.48 \pm 0.19$ & $9.55 \pm 0.25$ & $6.72 \pm 0.13$ & $6.58 \pm 0.13$ \\
\hline 5 & $11.19 \pm 0.02$ & $11.28 \pm 0.03$ & $5.34 \pm 0.02$ & $5.27 \pm 0.02$ & $9.53 \pm 0.13$ & $9.51 \pm 0.12$ & $6.63 \pm 0.09$ & $6.59 \pm 0.08$ \\
\hline 7 & $11.17 \pm 0.03$ & $11.30 \pm 0.02$ & $5.32 \pm 0.03$ & $5.27 \pm 0.03$ & $9.50 \pm 0.09$ & $9.54 \pm 0.19$ & $6.69 \pm 0.12$ & $6.62 \pm 0.15$ \\
\hline
\end{tabular}

${ }^{*}$ Mean of three values \pm Std Error.

Table 5. Effect of SC-CO+EO treatment on BD of watermelon and melon juices.

\begin{tabular}{|c|c|c|c|c|}
\hline \multicolumn{3}{|c|}{ Watermelon juice } & \multicolumn{2}{|c|}{ Melon juice } \\
\hline Day & Untreated $^{1}$ & $\mathrm{SC}-\mathrm{CO}_{2}+\mathrm{TEO}^{1}$ & Untreated $^{1}$ & ${\mathrm{SC}-\mathrm{CO}_{2}+\mathrm{TEO}^{1}}^{1}$ \\
\hline 0 & $1.12 \pm 0.01$ & $1.12 \pm 0.02$ & $1.09 \pm 0.01$ & $1.13 \pm 0.01$ \\
\hline 1 & $1.12 \pm 0.01$ & $1.12 \pm 0.01$ & $1.08 \pm 0.02$ & $1.40 \pm 0.01$ \\
\hline 3 & $1.11 \pm 0.02$ & $1.11 \pm 0.02$ & $1.08 \pm 0.03$ & $1.13 \pm 0.02$ \\
\hline 5 & $1.09 \pm 0.03$ & $1.1 \pm 0.03$ & $1.07 \pm 0.01$ & $1.14 \pm 0.03$ \\
\hline 7 & $1.07 \pm 0.03$ & $1.09 \pm 0.03$ & $1.08 \pm 0.02$ & $1.09 \pm 0.01$ \\
\hline
\end{tabular}


Table 6. Effects of SC-CO+EO treatment on watermelon juice $\mathrm{L}^{\star}, \mathrm{a}^{\star}$ and $\mathrm{b}^{\star}$ values after treatment $(0)$ and during storage (7 days).

\begin{tabular}{|c|c|c|c|c|c|c|}
\hline \multirow{2}{*}{ Day } & \multicolumn{3}{|c|}{ Untreated $^{1}$} & \multicolumn{3}{|c|}{ 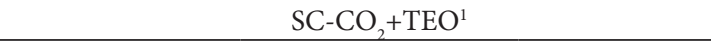 } \\
\hline & $\mathrm{L}^{*}$ & $\mathrm{a}^{*}$ & $b^{*}$ & $\mathrm{~L}^{*}$ & $a^{*}$ & $\mathrm{~b}^{*}$ \\
\hline 0 & $28.31 \pm 1.23$ & $19.34 \pm 1.23$ & $8.38 \pm 0.23$ & $30.87 \pm 1.23$ & $19.43 \pm 1.23$ & $8.58 \pm 0.23$ \\
\hline 1 & $29.29 \pm 1.10$ & $17.56 \pm 1.06$ & $9.12 \pm 0.12$ & $31.23 \pm 1.20$ & $19.65 \pm 1.14$ & $8.78 \pm 0.19$ \\
\hline 3 & $30.12 \pm 2.05$ & $16.61 \pm 1.09$ & $9.54 \pm 0.08$ & $31.17 \pm 2.06$ & $20.43 \pm 2.12$ & $8.82 \pm 0.22$ \\
\hline 5 & $30.46 \pm 2.14$ & $17.36 \pm 1.11$ & $9.58 \pm 0.11$ & $31.02 \pm 2.23$ & $21.76 \pm 2.08$ & $8.54 \pm 0.15$ \\
\hline 7 & $30.22 \pm 2.07$ & $17.44 \pm 1.16$ & $9.56 \pm 0.12$ & $31.68 \pm 2.07$ & $21.49 \pm 1.12$ & $8.23 \pm 0.10$ \\
\hline
\end{tabular}

${ }^{1}$ Control, Without application of SC- $\mathrm{CO}_{2}+\mathrm{EO}$.

Table 7. Effects of SC-CO+EO treatment on melon juice $\mathrm{L}^{\star}, \mathrm{a}^{\star}$ and $\mathrm{b}^{\star}$ values after treatment $(0)$ and during storage (7 days).

\begin{tabular}{|c|c|c|c|c|c|c|}
\hline \multirow{2}{*}{ Day } & \multicolumn{3}{|c|}{ Untreated $^{1}$} & \multicolumn{3}{|c|}{ 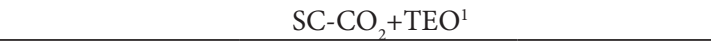 } \\
\hline & $\mathrm{L}^{*}$ & $a^{*}$ & $\mathrm{~b}^{*}$ & $\mathrm{~L}^{*}$ & $a^{*}$ & $b^{*}$ \\
\hline 0 & $24.25 \pm 1.12$ & $10.89 \pm 0.12$ & $19.75 \pm 1.12$ & $25.12 \pm 1.12$ & $10.45 \pm 0.12$ & $19.70 \pm 1.14$ \\
\hline 1 & $26 \pm 1.18$ & $11.67 \pm 0.15$ & $19.65 \pm 1.08$ & $26.10 \pm 2.18$ & $10.10 \pm 0.15$ & $19.66 \pm 2.08$ \\
\hline 3 & $25 \pm 1.10$ & $11.34 \pm 0.16$ & $18.98 \pm 1.06$ & $25.79 \pm 1.10$ & $9.62 \pm 0.16$ & $19.43 \pm 1.06$ \\
\hline 5 & $26 \pm 1.09$ & $11.45 \pm 0.09$ & $19.45 \pm 1.18$ & $26.76 \pm 1.09$ & $9.30 \pm 0.09$ & $19.45 \pm 1.18$ \\
\hline 7 & $25 \pm 1.12$ & $11.26 \pm 0.013$ & $19.24 \pm 1.20$ & $27.97 \pm 2.12$ & $9.08 \pm 0.25$ & $19.69 \pm 2.20$ \\
\hline
\end{tabular}

of juice. The results of this study demonstrated the efficacy of SC-CD+TOE in inactivating microorganisms and maintaining the quality of juices. During the measurement, the juice color values $\left(\mathrm{L}^{*}, \mathrm{a}^{*}\right.$ and $\left.\mathrm{b}^{*}\right)$ were not uniform. The color settled out in a few hours if left undisturbed. Therefore, it was necessary to blend juice each day. Note that after 7 days, the SC-CD+TEO treated juice $L^{\star}$ values stayed steady. Casas-Forero et al. (2020) indicated that centrifugal block freezing was increased the solid contents of the blueberry juice and the final color was darker than the fresh juice. The lightness of watermelon and melon juice significantly $(\mathrm{p}<0.05)$ increased between 8 and $12 \%$ after treatments with SC-CD+TEO, respectively, and slightly decreased during storage.

\section{Conclusions}

This study evaluated SC-CD+TEO non-thermal treatment mechanism to process watermelon and melon juice. SC-CD+TEO combination sufficiently inactivated pathogenic and spoilage bacteria. SC-CD+TEO combinations at $10.13 \mathrm{MPa}$ were able to reduce all S. Typhimurium, E. coli and K. pneumoniae in TSB and juice. The mechanism of bacterial inactivation by SC-CD and TEO can be typically linked to the structure of bacteria, the type of microorganisms, the type of suspending medium, type of food, pressure level and exposure time. The combination of SC-CD with TEO as a hurdle approach can effectively enhance food safety, allow milder process conditions, increases product quality and reduces process costs. Using this technology, TSS and $\mathrm{BD}$ remained the same after the treatment storage of juices. The $\mathrm{pH}$ of juice slightly reduced after treatments and stable throughout the storage. Hurdle effects (SC-CD, TEO and acidity) represent an alternative to thermal processing in the shelf life of heat-labile watermelon and melon juices.

\section{Acknowledgements}

This research has been financially supported by the Gaziantep University Research Fund.

\section{References}

Ames, G. F. (1968). Lipids of Salmonella typhimurium and Escherichia coli: structure and metabolism. Journal of Bacteriology, 95(3), 833843. http://dx.doi.org/10.1128/JB.95.3.833-843.1968. PMid:4868364.

Band, V. I., \& Weiss, D. S. (2014). Mechanisms of antimicrobial peptide resistance in gram-negative bacteria. Antibiotics, 4(1), 18-41. http:// dx.doi.org/10.3390/antibiotics4010018. PMid:25927010.

Bhattacharjee, C., Saxena, V. K., \& Dutta, S. (2018). Analysis of fouling and juice quality in crossflow ultrafiltration of watermelon juice. Food Science and Technology, 38(Suppl. 1), 71-76. http://dx.doi. org/10.1590/1678-457x.15217.

Boskovic, M., Djordjevic, J., Ivanovic, J., Janjic, J., Zdravkovic, N., Glisic, M., Glamoclija, N., Baltic, B., Djordjevic, V., \& Baltic, M. (2017). Inhibition of Salmonella by thyme essential oil and its effect on microbiological and sensory properties of minced pork meat packaged under vacuum and modified atmosphere. International Journal of Food Microbiology, 258, 58-67. http://dx.doi.org/10.1016/j. ijfoodmicro.2017.07.011. PMid:28759796.

Carvalho, M., Albano, H., \& Teixeira, P. (2018). In vitro antimicrobial activities of various essential oils against pathogenic and spoilage microorganisms. Journal of Food Quality and Hazards Control, 5(2), 41-48. http://dx.doi.org/10.29252/jfqhc.5.2.3.

Casas-Forero, N., Orellana-Palma, P., \& Petzold, G. (2020). Influence of block freeze concentration and evaporation on physicochemical properties, bioactive compounds and antioxidant activity in blueberry juice. Food Science and Technology, 40(Suppl. 2), 387-394. http:// dx.doi.org/10.1590/fst.29819.

Chung, Y.-K., \& Yousef, A. E. (2008). Inactivation of barotolerant strains of Listeria monocytogenes and Escherichia coli O157:H7 by ultrahigh pressure and tert-butylhydroquinone combination. Journal of Microbiology, 46(3), 289-294. http://dx.doi.org/10.1007/ s12275-008-0090-6. PMid:18604498.

Corradini, M. G., \& Peleg, M. (2012). The kinetics of microbial inactivation by carbon dioxide under high pressure. In M. Balaban \& G. Ferrentino (Eds.), Dense phase carbon dioxide: food and pharmaceutical applications (pp. 135-155). Iowa: John Wiley and Sons. http://dx.doi.org/10.1002/9781118243350.ch7. 
Erkmen, O. (2000). Antimicrobial effects of carbon dioxide on Brochothrix thermosphacta in broth and foods. Journal of the Science of Food and Agriculture, 80(9), 1365-1370. http://dx.doi.org/10.1002/10970010(200007)80:9<1365::AID-JSFA652>3.0.CO;2-P.

Erkmen, O. (2012). Effects of dense phase carbon dioxide on vegetative cells. In M. Balaban \& G. Ferrentino (Eds.), Dense phase carbon dioxide: food and pharmaceutical applications (pp. 67-96). Iowa: John Wiley \& Sons. http://dx.doi.org/10.1002/9781118243350.ch4

Erkmen, O. (2015). Basic methods for the microbiological analysis of foods (3rd ed). Ankara: Nobel Academic Publishing Education Consultancy Trade Co. Ltd. Retrieved from https://www.nobelyayin. com/detay.asp? $\mathrm{u}=1994$

Erkmen, O., \& Bozoglu, T. F. (2016a). Factors affecting microbial growth in foods. In O. Erkmen \& T. F. Bozoglu (Eds.), Food microbiology: principles into practice (Vol. 1: Microorganisms related to foods, foodborne diseases and food spoilage, pp. 91-106). Chichester: John Wiley \& Sons. http://dx.doi.org/10.1002/9781119237860.ch05.

Erkmen, O., \& Bozoglu, T. F. (2016b). Foodborne invasive infections. In O. Erkmen \& T. F. Bozoglu (Eds.), Food microbiology principles into practice (Vol. 2: Microorganisms in food preservation and processing, pp. 138-170). Chichester: John Wiley \& Sons. http:// dx.doi.org/10.1002/9781119237860.ch08.

Erkmen, O., \& Bozoglu, T. F. (2016c). Food preservation by high temperatures. IIn O. Erkmen \& T. F. Bozoglu (Eds.), Food microbiology principles into practice (Vol. 2: Microorganisms in food preservation and processing, pp. 12-33). Chichester: John Wiley \& Sons. http:// dx.doi.org/10.1002/9781119237860.

Fonteles, T. V., Costa, M. G. M., Jesus, A. L. T., Miranda, M. R. A., Fernandes, F. A. N., \& Rodrigues, S. (2012). Power ultrasound processing of cantaloupe melon juice: effects on quality parameters. Food Research International, 48(1), 41-48. http://dx.doi.org/10.1016/j. foodres.2012.02.013.

Food and Agriculture Organization of the United Nations - FAO. (2011. Microbial hazards and melons: Codex committee on food hygiene working group on the development of an annex on methods for the Code of Hygienic Practice for fresh fruits and vegetables (CAC/RCP 53-2003). Rome: FAO.

Gui, F., Wu, J., Chen, F., Liao, X., Hu, X., Zhang, Z., \& Wang, Z. (2006). Change of polyphenol oxidase activity, color, and browning degree during storage of cloudy apple juice treated by supercritical carbon dioxide. European Food Research and Technology, 223(3), 427-432. http://dx.doi.org/10.1007/s00217-005-0219-3.

Juven, B. J., Kanner, J., Schved, F., \& Weisslowicz, H. (1994). Factors that interact with the antibacterial action of thyme essential oil and its active constituents. The Journal of Applied Bacteriology, 76(6), 626-631. http://dx.doi.org/10.1111/j.1365-2672.1994.tb01661.x. PMid:8027009.

Liu, Y., Hu, X., Zhao, X., \& Song, H. (2012). Combined effect of highpressure carbon dioxide and mild heat treatment on overall quality parameters of watermelon juice. Innovative Food Science \& Emerging Technologies, 13, 112-119. http://dx.doi.org/10.1016/j.ifset.2011.11.001.

Marszałek, K., Woźniak, Ł., Barba, F. J., Skąpska, S., Lorenzo, J. M., Zambon, A., \& Spilimbergo, S. (2018). Enzymatic, physicochemical, nutritional and phytochemical profile changes of apple (Golden Delicious L.) juice under supercritical carbon dioxide and longterm cold storage. Food Chemistry, 268, 279-286. http://dx.doi. org/10.1016/j.foodchem.2018.06.109. PMid:30064759.

Martino, L., Feo, V., Fratianni, F., \& Nazzaro, F. (2009). Chemistry, antioxidant, antibacterial and antifungal activities of volatile oils and their components. Natural Product Communications, 4(12), 1741-1750. http://dx.doi.org/10.1177/1934578X0900401226. PMid:20120118.
Moussé, W., Adjanohoun, A., Sina, H., Noumavo, P. A., Ahissin, D., \& Baba-Moussa, L. (2016). Klebsiella pneumoniae isolated from street foods: characterization for extended spectrum $\beta$-lactamases production and antibiotics resistance profile. Biochemical and Biotechnological Research, 4(2), 27-37.

Muller, M. (2014). The occurrence of microbial hazards and succession of Enterobacteriaceae on fresh-cut fruit during minimal processing and storage (Master's thesis). Department of Food Science, Faculty of Natural and Agricultural Science, University of Pretoria, Pretoria.

Nazzaro, F., Fratianni, F., Martino, L., Coppola, R., \& de Feo, V. (2013). Effect of essential oils on pathogenic bacteria. Pharmaceuticals, 6(12), 1451-1474. http://dx.doi.org/10.3390/ph6121451. PMid:24287491.

Ndiaye, N. F., Sadji, M., Zongo, C., Traore, Y., Sall, M. D., \& Traore, A. (2018). Parboiling paddy rice with watermelon (citrullus lanatus) juice. Journal of Microbiology \& Experimentation, 6(2), 124-125.

Oreopoulou, A., Tsimogiannis, D., \& Oreopoulou, V. (2019). Extraction of polyphenols from aromatic and medicinal plants: an overview of the methods and the effect of extraction parameters. In R. R. Watson (Ed.), Polyphenols in plants: isolation, purification and extract preparation (2nd ed., pp. 243-259). Maryland: Elsevier Inc. http:// dx.doi.org/10.1016/B978-0-12-813768-0.00025-6.

Pei, L., Hou, S., Wang, L., \& Chen, J. (2018). Effects of high hydrostatic pressure, dense phase carbon dioxide, and thermal processing on the quality of Hami melon juice. Journal of Food Process Engineering, 41(6), e12828. http://dx.doi.org/10.1111/jfpe.12828.

Sadji, M., Ndiaye, N. F., Lopy, M. S., Zongo, C., Traore, Y., Diop Sall, M., \& Traore, A. (2018). Production of puree and watermelon (Citrullus lanatus) juice usable in bread making. Journal Food Nutrition and Population Health, 2(1), 1-3. http://dx.doi.org/10.21767/25770586.100031 .

Seyyednejad, S. M., Motamedi, H., Vafei, M., \& Bakhtiari, A. (2014). The antibacterial activity of cassia fistula organic extracts. Jundishapur Journal of Microbiology, 7(1), e8921. http://dx.doi.org/10.5812/ jjm.8921. PMid:25147664.

Sikin, A. M., Walkling-Ribeiro, M., \& Rizvi, S. S. H. (2016). Synergistic effect of supercritical carbon dioxide and peracetic acid on microbial inactivation in shredded Mozzarella-type cheese and its storage stability at ambient temperature. Food Control, 70, 174-182. http:// dx.doi.org/10.1016/j.foodcont.2016.05.050.

Silva, E. K., Meireles, M. A. A., \& Saldaña, M. D. A. (2020). Supercritical carbon dioxide technology: A promising technique for the nonthermal processing of freshly fruit and vegetable juices. Trends in Food Science \& Technology, 97, 381-390. http://dx.doi.org/10.1016/j. tifs.2020.01.025.

Smid, E. J., \& Gorris, L. G. M. (2007). Natural antimicrobials for food preservation. In M. S. Rahman (Ed.), Handbook of food preservation (2nd ed., pp. 237-258). New York: CRC Press.

Souza, C. C., Oliveira, C. A., Pires, J. F., Pimentel, T. C., Raices, R. S. L., \& Nogueira, L. C. (2020). Physicochemical characteristics and sensory acceptance of a mixed beverage based on organic apple juice and cardamom tea (Elettaria cardamomum) with allegation of functional properties. Food Science and Technology, 40(Suppl. 2), 669-676. http://dx.doi.org/10.1590/fst.35419.

Spilimbergo, S., Komes, D., Vojvodic, A., Levaj, B., \& Ferrentino, G. (2013). High pressure carbon dioxide pasteurization of fresh-cut carrot. The Journal of Supercritical Fluids, 79, 92-100. http://dx.doi. org/10.1016/j.supflu.2012.12.002.

Tutar, U. (2018). Investigation of antibacterial and anti-biofilm activity of Thymbra spicata essential oil on multidrug-resistant Pseudomonas aeruginosa strains. Cumhuriyet Science Journal, 39(3), 650-657. http://dx.doi.org/10.17776/csj.410749. 
Walsh, K. A., Bennett, S. D., Mahovic, M., \& Gould, L. H. (2014). Outbreaks associated with Cantaloupe, Watermelon and Honeydew in the United States, 1973-2011. Foodborne Pathogens and Disease, 11(12), 945-952. http://dx.doi.org/10.1089/fpd.2014.1812. PMid:25407556.

Wang, Y., Li, W., Ma, Y., Zhao, X., \& Zhang, C. (2018). Research article effect of thermal treatments on quality and aroma of watermelon juice. Journal of Food Quality, 2018, 9242675. http://dx.doi. org/10.1155/2018/9242675.

Zhou, L., Wang, Y., Hu, X., Wu, J., \& Liao, X. (2009). Effect of high pressure carbon dioxide on the quality of carrot juice. Innovative Food Science \& Emerging Technologies, 10(3), 321-327. http://dx.doi. org/10.1016/j.ifset.2009.01.002. 